\title{
症例報告
}

\section{食道癌術後の乳糜胸に対してオクトレオチド投与を 含めた保存的加療を行った 1 例}

\author{
久保秀文，中須賀千代，多田耕輔，宮原 誠，長谷川博康 \\ 綜合病院社会保険德山中央病院 外科＼cjkstart周南市孝田町 $1-1$ （ ₹745-8522）
}

Key words : 食道癌, 乳糜胸, 酢酸オクトレオチド

和文抄 録

われわれは食道癌術後に発生した難治性の乳糜胸 に対し酢酸オクトレオチド投与を含めた保存的治療 を行った 1 例を経験した。症例は52歳男性，2012年 9 月に進行食道癌 ; c-T3 N1, M0, Stage II の診断で術 前化学療法を施行し11月に右開胸食道亜全摘術，3 領域リンパ節郭清術を施行した。術後第 3 病日より 右胸腔ドレーン排液量が増加し乳糜胸と診断した。 低脂肪食摂取を継続し同時に酢酸オクトレオチドを 連日投与した。一時的に排液量は漸減したが $500 \mathrm{ml} /$ 日以上の排液が持続した。 その後ミノマイシンを胸 腔内へ追加注入したがすぐには奏効が見られなかっ た。脂肪制限食と中心静脈栄養（total parenteral nutrition：以下，TPN）を併用した栄養管理を継続 させ，再度の酢酸オクトレオチド投与を連日行った ところ徐々に排液量の減少を認め, 術後50日目にド レーン抜去し59日目に軽快退院した。2000年以降に 報告された食道癌術後乳糜胸の 24 例を集計して多角 的に検討したので文献的考察を加えて報告する.

はじめに

食道癌術後の乳糜胸は $1.1 \sim 3.2 \%^{11)}$ と低い発生率 ではあるがその治療には難渋することがあり，治療 法も確立されていない．今回われわれは食道癌術後 の乳糜胸を経験しオクトレオチド投与を含めた保存

平成 25 年 7 月 22 日受理
的加療を行ったので報告する.

\section{症例}

患 者：65歳, 男性.

主 訴 : 腹痛.

既往歴：特記すべき事項なし。

現病歴：2012年 7 月頃より嚥下困難を自覚してい た，徐々に症状が増悪したため同年 9 月前医を受診 した，上部胃消化管で食道狭窄を認め, 生検にて食 道癌と診断されたため当科に紹介された。

既往歴：特記すべきことなし.

生活歴：喫煙 30 歳まで 30 本/日×10年間.

飲酒 日本酒 1 合 $/$ 日.

入院時身体所見：身長 $160 \mathrm{~cm}$ ，体重 $57 \mathrm{~kg}$ ．腹部は 平坦で圧痛・腹水を認めず，表在リンパ節，肝，脾 は触知せず．

入院時血液所見 : 血算・生化学血液検查所見には異 常を認めず, 腫瘍マーカーSCC, CEAも正常範囲で あった。

上部消化管内視鏡検査所見 : 門歯列より $30 \mathrm{~cm}$ 部 位に狭窄を認め（図 $1 \mathrm{a}$ ), 生検にて扁平上皮癌と診 断された。

胸部CT所見：気管分岐レベルの食道に壁肥厚所見 あり。縦隔内および肺門のリンパ節に異常は認めな かった（図 $1 \mathrm{~b}$ ).

PET所見：気管分岐下レベルの食道壁肥厚に一致し て高集積を認めた．また腫瘍部の左下方に結節粎の集 積を認め縦隔内のリンパ節転移が疑われた（図 $1 \mathrm{c}$ ). 


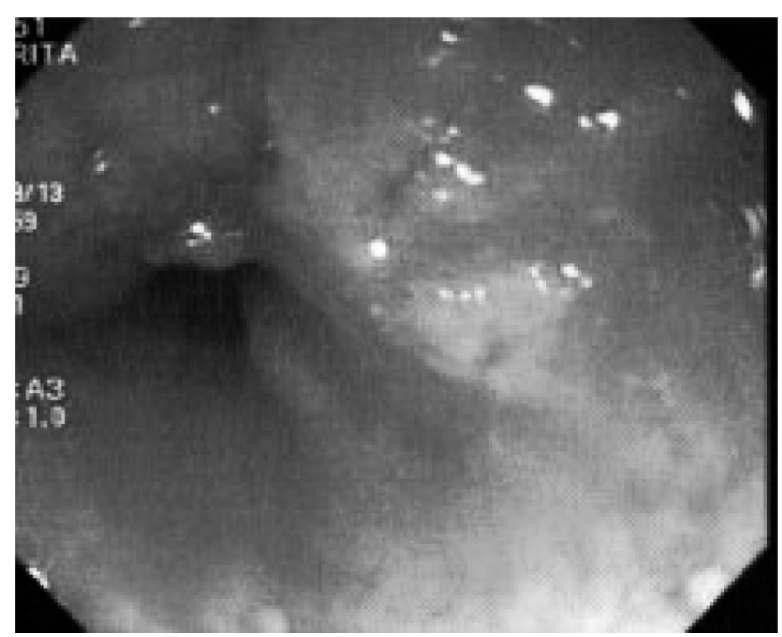

図 $1 \mathrm{a}$ 上部消化管内視鏡

門歯列より $30 \mathrm{~cm}$ の胸部食道に全周性の狭窄を認めた.

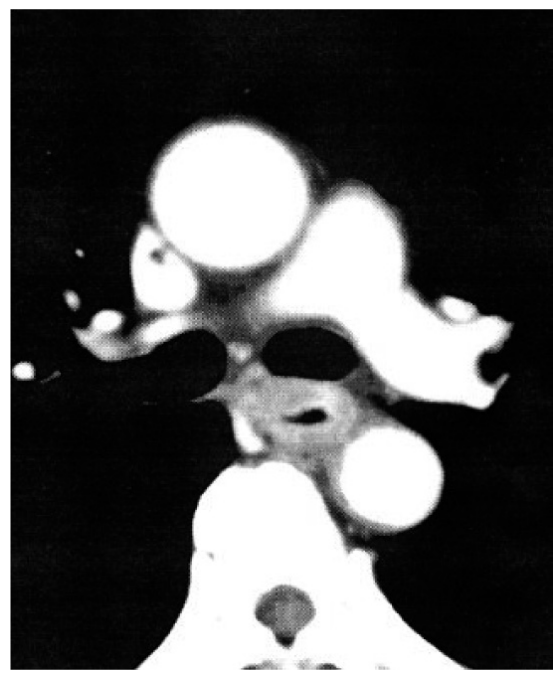

図 1 b CT所見

気管分岐レベルの食道に壁肥厚所見あり。上位縦隔や肺 門のリンパ節に異常は認めなかった.

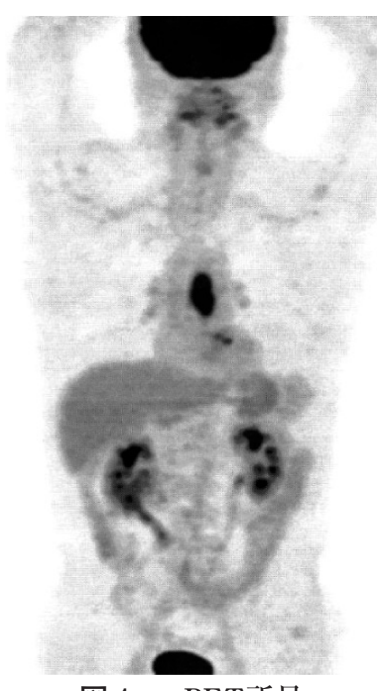

図1c PET所見

気管分岐下レベルの食道壁肥厚に高集積を認め, 腫瘍部 より左下方の縦隔リンパ節転移が疑われた。

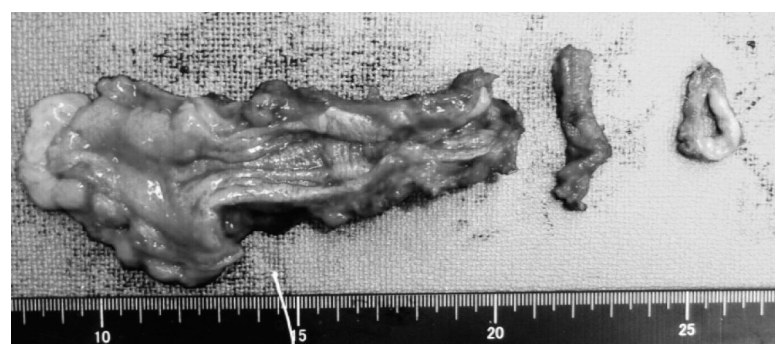

図2 a 切除標本

胸部中部食道に $5 \times 3 \mathrm{~cm}$, 全周の 3 型腫瘍を認めた.

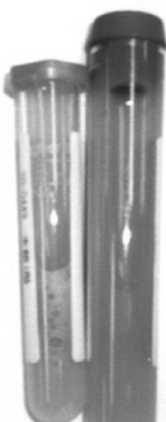

図 $2 \mathrm{~b}$ 胸水肉眼所見

胸水は乳白色で成分分析にて脂肪酸，トリグリセリドの 高值を示した.

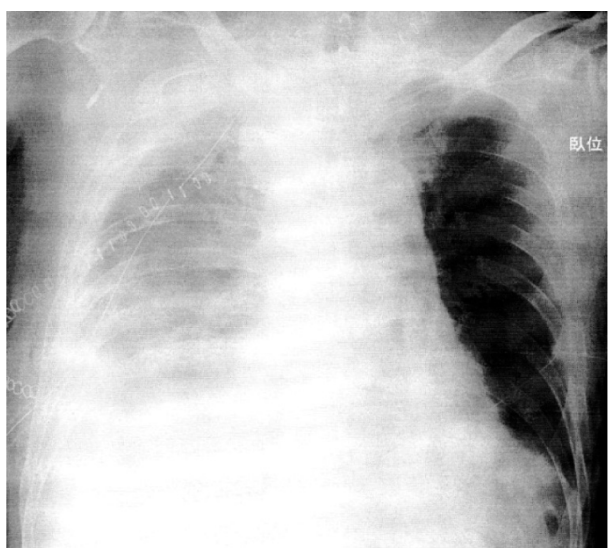

図3a 胸部X-P像（術後28病日）

ドレーンの一時的閉塞で右胸腔内に多量の胸水貯留を認 めた.

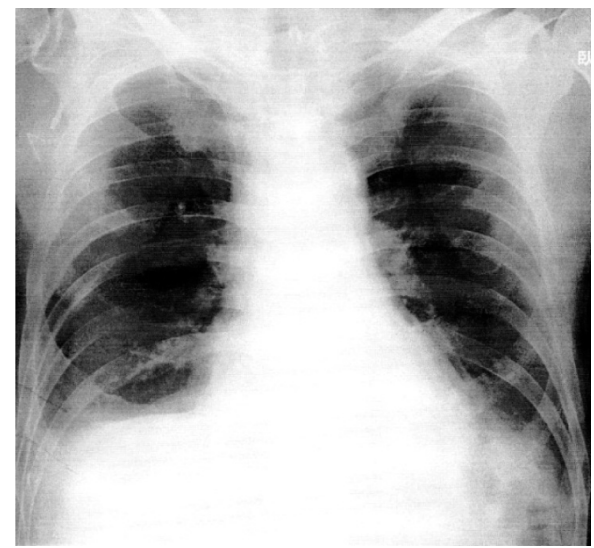

図 3b 胸部X-P像（退院時）

胸水貯留は消失した。 
以上ょり cT $2 \sim 3 \mathrm{cN} 2 \mathrm{M} 0$ Stage III と診断し Nedaplatin, Fluorouracil（5Fu）による術前化学療 法を施行した，術前化学療法の治療効果は「安定」 であったため2012年11月右開胸開腹食道亜全摘術, 3 領域郭清, 胸骨後経路颈部食道胃管吻合術を施行 した（図 $2 \mathrm{a}$ )。術中，両側開胸となったため術後両 側胸腔ドレーンを留置した。なお，術中は胸管を損 傷しないよう温存してリンパ節郭清を行った。病理 結果はmoderate differentiated squamous cell carcinoma, pT3pN2M0, Stage III の診断であった.

術後経過 : 術後の全身状態は良好であったが第 3 病 日より胸水が増加し食事開始とともにその性状は白 濁した（図 $2 \mathrm{~b}$ )。胸水の成分分析で脂肪酸，トリ グリセリドの高值を示したため乳糜胸の診断を下し た。低脂肪食, 経静脈栄養を継続し早期よりソマト スタチンアナログであるオクトレオチド $50 \mu \mathrm{g}$ 一 日 3 回皮下投与したところ徐々に排液量は溸減し た。術後21日目には $500 \mathrm{ml} /$ 日以下の排液となった ためオクトレオチドを一旦中止したところ排液量は 再び漸増した（図 $3 \mathrm{a}$ )。ミミノマイシン $200 \mathrm{mg}+20 \%$ ブドウ糖液 $250 \mathrm{cc}$ を 7 日間胸腔内へ注入したが明ら かな奏効は見られなかった。開胸再手術も視野に入 れていたが患者の強い保存加療の希望があり, 脂肪 制限食とTPN併用投与にて栄養管理を継続し術後 37 病日よりオクトレオチド $100 \mu \mathrm{g}$ を一日 3 回皮下 投与として 7 日間継続した。 その後胸水は減少し摂 食開始しても排液量の増加や白濁もないため術後50 日目に胸腔ドレーンを抜去し術後59日目に軽快退院 となった（図 $3 \mathrm{~b}$ )。なお，図 4 へ本症例の時間経 過に伴う胸水排液量を呈示した. 現在, 退院後 3 力 月経過するが胸水の再譻留を認めていない.

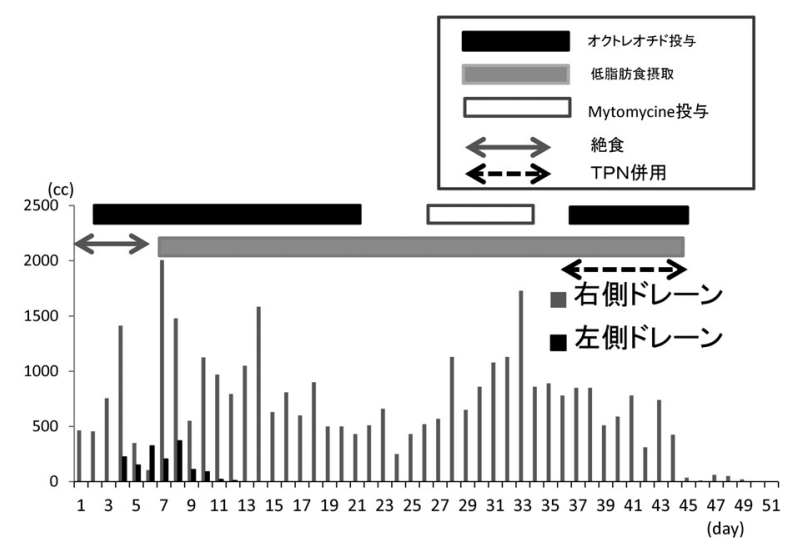

図4 本症例の臨床経過（胸腔ドレーン排液量）
考察

食道癌術後の胸水貯留にはその排液量と共にその 性状に注意を払う必要がある。.まず術後の胸水が連 日 $500 \mathrm{ml} /$ 日以上の場合は胸管損傷などによる乳糜 胸を疑うべきである。乳糜胸では脂肪酸の摂取によ って胸水が乳白色になるのが特徴であるが，その証 明にはSudan III染色による脂肪滴の検出, 胸水中 の脂肪酸，トリグリセリドが血清中より高值を示し 好酸球, リンパ球の存在を認めるとされている ${ }^{2)}$. 本症例でも食事摃取により胸水は乳白色化し胸水の 成分分析で脂肪酸，トリグリセリドの高值を示した ため乳糜胸の診断を下した.

乳糜胸に対する治療としては保存的加療と手術療 法に大別される，乳糜胸の保存的治療としては完全 静脈栄養, 脂肪制限食などによる栄養管理が基本で ある. 脂肪制限食とするか絶食・完全経静脈栄養と するかについて木村ら ${ }^{3)}$ は脂肪制限食群の方が有意 に治癒までの期間が短かったとしており，まずは脂 肪制限食での治療開始が望ましいと考えられる。こ れら栄養療法のみで改善が見られない時に薬物療法 が適用されるがこれには胸腔内へ薬物を注入する癒 着療法と薬物のリンパ管および静脈投与法とがあ る.

50\%ブドウ糖， OK- $432 ，$ ミノマイシンなどを胸 腔内へ直接注入する瘾着療法はその効果が不確実で あり局所の炎症や癒着を促すため手術が必要となっ た時には剥離操作を困難にさせることが予想され， first choiceには向かない.

薬物のリンパ管内投与法にはリピオドールが, 静 脈投与法としてはオクトレオチドがある。 近年, リ ピオドールを用いたリンパ管造影により漏出部位の 同定と同部位への塞栓効果により治癒を促すとされ ている ${ }^{4,5)}$ が，実施方法がやや困難であり治療抵抗 症例の報告 ${ }^{6)}$ もあり，また肺塞栓などの合併症を誘 発する可能性は否定できない.

オクトレオチドはソマトスタチンレセプターを介 して消化液分泌抑制と胸管平滑筋収縮による胸管内 流量の減少を来すと推測されている7，8). その臨床 効果は多数報告されているが比較的短期間である 1 〜 週間以内に改善が認められたとする報告が多い $5,9,10)$ ． その副作用として血糖変動，嘔気，心窝部 不快感, 肝機能障害, 徐脈, 胆石形成などが挙げら 
れているが，過去の報告では臨床上，重篤なものは 報告されておらず本症例での投与量，投与方法につ いては癌性消化管閉塞に対する投与量に準じたが本 症例でもこれらの副作用は認めなかった。

ソマトスタチンは迷走神経を介して平滑筋へ作用 するが，進行食道癌ではリンパ郭清に伴い迷走神経 切離がなされるためその効果が得られない可能性が 指摘されている ${ }^{4,111}$.

本邦で 2000 年以降に報告された食道癌術後乳糜胸 の報告は医学中央雑誌でわれわれが調べた限り, 本 症例を含めて 24 例であった（表 1 ）。集計24例中才 クトレオチドは11例に投与されており，11例中本症 例を含めた 5 例5，8，9，12) にこの薬剤を中心とした保 存加療のみで治㾻が得られていた。 しかし他の 5 例 4, 10, 13-15) ではオクトレオチド単独では効果がなく手 術やリピオドール造影などがその後追加されてい た. 1 例 ${ }^{24)}$ は術後の補助治療としてオクトレオチド が投与されていた。11例全例が2006年以降の比較的 最近の症例でありオクトレオチドの副作用の低さと 手術移行例に対しても術野に瘉着などの影響を与え ないことを考えると乳糜胸への第 1 選択として頻用 されている薬剤といえよう。比較的高価な薬剤であ るため今後, 保険適応となることが望まれる.

次に手術療法であるがその手術適応としては1 $1500 \mathrm{ml} /$ 日以上の排液が 5 日間持続する，214日間 排液が減少しない，(3)栄養障害を伴うとするSalle ら ${ }^{16)}$ の基準が用いられることが多いが, Robinson ら 17) は大人で $500 \mathrm{ml} /$ 日を超える乳糜胸が $2 \sim 3$ 週 間続くとき, Pattersonら ${ }^{18)}$ は $1000 \mathrm{ml} /$ 日以上の乳糜 胸が 7 日以上持続するときとしている。実臨床では
患者の全身状態とのバランスで考慮しなければなら ずその判断は必ずしも容易ではないと考えられる.

大橋ら ${ }^{19)}$ は食道癌術後乳糜胸を術後 $2 \sim 4$ 日目の 早期発症と 7 日目以降の晚期発生型に分けて検討 し, 早期型は直接漏出部位を確認しうる場合があり 積極的に手術を施行するべきであるとし，晚期型で は保存加療を钊めている。 また手術を施行する際に は胸管走行自体が元々多くの破格があり, 術前に胸 管の損傷部を必ず同定しておく必要もあろう。今回 の集計では11例10, 12, 14, 20-27) が手術での胸管結禁術が 施行されており, 再手術施行日は初回手術後 $3 \sim 35$ 日に渡っており平均術後18.5日目と手術症例におい てもほとんどの症例が 2 週間以上の保存加療がなさ れていた。

手術方法として 11 例中 8 例が胸腔鏡下の胸管クリ ッピング手術が選択されており, 再開胸に比べて胸 腔鏡手術が低侵襲であり拡大視効果による乳糜漏出 部位の同定に有用であると考えられる。手術成績と して 9例は術後短期間で乳糜胸の治癒を認めたもの の 3 例 $3,23,24)$ (25\%) は手術後も乳糜胸は持続し, 1 例23) は術後重篤なカイローマの発生を惹起してい た。手術成績は集計上では手術単独での成績は決し て完全とは言えず，やはり全身状態をよく吟味して 適応を決定する必要があ万う。本症例でもまず保存 的治療として胸腔ドレーンの扦入, 高カロリー輸液 を併用した低脂肪食摂取, 酢酸オクトレオチド, ミ ノマイシン胸腔内注入の併用を行った。

本症例では極端な循環障害や栄養障害を来さずア ルブミンをはじめとする血清蛋白は比較的維持され たため保存療法を継続させたが, 先の大橋ら ${ }^{19)}$ の意

表 1 本邦における2000年以降の食道癌術後乳糜胸の報告例

\begin{tabular}{|c|c|c|c|c|c|c|c|c|}
\hline 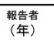 & 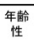 & 手術 & Stage & 䓪剂 & 副作用 & 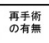 & 徚式 & 転帰 \\
\hline $\begin{array}{l}\text { 毛利 }_{2001} \\
2000\end{array}$ & $\begin{array}{l}69 \\
\text { 男 }\end{array}$ & 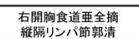 & 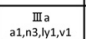 & $\begin{array}{c}\text { OK4332 10KE } \\
\text { MINo 200mg } 3 \text { 日 }\end{array}$ & \begin{tabular}{|l|} 
発祭 \\
\end{tabular} & ない & - & $\begin{array}{l}\text { PODG5: } \\
\text { 泿院 }\end{array}$ \\
\hline $\begin{array}{l}\text { 木/Fら } \\
2002\end{array}$ & $\begin{array}{l}64 \\
\text { 男 }\end{array}$ & 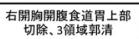 & $\underset{T 4, N 4, M 0}{\mathbb{N V}}$ & - & - & $\begin{array}{l}\text { कுy } \\
\text { PODS }\end{array}$ & 胸管結禁 & $\begin{array}{c}\text { POD401/ } \\
\text { 退院 }\end{array}$ \\
\hline $\begin{array}{l}300255 \\
2002\end{array}$ & $\begin{array}{l}72 \\
\text { 男 }\end{array}$ & 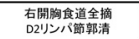 & \begin{tabular}{c|c|}
1 \\
$T 1 b, N o, M 0$ \\
\end{tabular} & M1N0400mg/日 2日 & 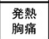 & な & - & 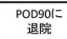 \\
\hline $\begin{array}{l}\text { 西潈战 } \\
2003\end{array}$ & $\begin{array}{l}71 \\
\text { 男 }\end{array}$ & 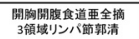 & 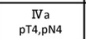 & 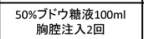 & t大 & ない & - & $\begin{array}{l}\text { POD751= } \\
\text { 退院 }\end{array}$ \\
\hline $\begin{array}{l}\text { 素鳥 } \\
2003\end{array}$ & $\begin{array}{l}71 \\
\text { 男 }\end{array}$ & 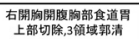 & $\begin{array}{c}1 \\
\mathrm{p} T 1 \mathrm{~b}, \mathrm{~N}, \mathrm{MO} \\
\end{array}$ & - & - & $\begin{array}{l}\text { क़! } \\
\text { POO3 }\end{array}$ & 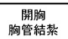 & 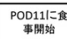 \\
\hline $\begin{array}{l}\text { 增南5 } \\
2004\end{array}$ & $\begin{array}{l}61 \\
\text { 男 }\end{array}$ & 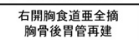 & $\underset{\mathrm{T3}, \mathrm{NI} 3 \mathrm{MO}}{\mathbb{I I}}$ & リビオドール7m投与 & \begin{tabular}{|l|} 
なし \\
\end{tabular} & ない & - & 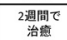 \\
\hline $\begin{array}{l}\text { 上吉原5 } \\
2005\end{array}$ & $\begin{array}{l}67 \\
\text { 男 }\end{array}$ & 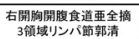 & 記戴札 & - & - & $\begin{array}{l}\text { あり } \\
\text { P0029 }\end{array}$ & 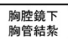 & 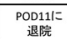 \\
\hline $\begin{array}{l}\text { 綀林的 } \\
2005\end{array}$ & $\begin{array}{l}57 \\
\text { 男 }\end{array}$ & 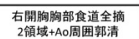 & $\begin{array}{c}\mathbb{N} \\
\text { T3N1M1 }\end{array}$ & 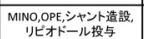 & \begin{tabular}{|l|} 
発繁 \\
\end{tabular} & कり & 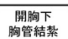 & 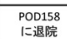 \\
\hline 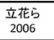 & $\begin{array}{l}54 \\
\text { 男 }\end{array}$ & 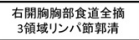 & 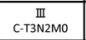 & $\begin{array}{c}\text { オ外しオヂ } \\
\text { OK-432 }\end{array}$ & \begin{tabular}{|l|l|}
$\alpha$ \\
\end{tabular} & 款 & - & 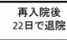 \\
\hline 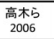 & $\begin{array}{l}42 \\
\text { 男 }\end{array}$ & 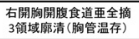 & $\begin{array}{c}\text { III } \\
\text { T3N1MO }\end{array}$ & $\begin{array}{l}\text { Ope, } \\
\text { オターオオF150ug }\end{array}$ & な & ない & 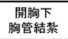 & 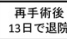 \\
\hline $\begin{array}{l}\text { 鬼賏5 } \\
2006\end{array}$ & $\begin{array}{l}55 \\
\text { 男 }\end{array}$ & 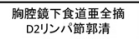 & \begin{tabular}{c|c|} 
III \\
pт11N2MO
\end{tabular} & - & - & $\begin{array}{l}\text { क山 } \\
\times 2\end{array}$ & 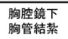 & 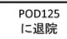 \\
\hline $\begin{array}{l}\text { 山田ら } \\
2006 \\
\text { 2006 }\end{array}$ & $\begin{array}{l}51 \\
\text { 男 }\end{array}$ & $\begin{array}{l}\text { 食道型全摘 } \\
\text { 3领域郭情 }\end{array}$ & $\begin{array}{c}\mathrm{II} \\
\text { T2N1M0 }\end{array}$ & 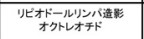 & 乱 & 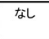 & - & $\begin{array}{c}\text { PoDs5l= } \\
\text { 迟院 }\end{array}$ \\
\hline
\end{tabular}

\begin{tabular}{|c|c|c|c|c|c|c|c|c|}
\hline $\begin{array}{l}\text { 辋㶵者 } \\
\text { (年) }\end{array}$ & 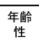 & 手術 & Stage & 菜削/量 & 甽作用 & 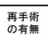 & 粥式 & 転㴆 \\
\hline $\begin{array}{l}\text { 能野放 } \\
2007\end{array}$ & $\begin{array}{l}55 \\
\text { 男 }\end{array}$ & 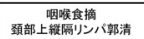 & $\begin{array}{c}\text { IVa } \\
\text { TanzMO }\end{array}$ & 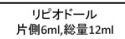 & 机 & 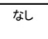 & - & 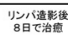 \\
\hline $\begin{array}{l}\text { 清水占 } \\
2008\end{array}$ & \begin{tabular}{|l|}
$\begin{array}{l}67 \\
\text { 男 }\end{array}$ \\
\end{tabular} & 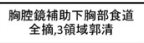 & 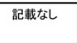 & な & - & $\begin{array}{l}\text { क5! } \\
\text { Poo17 }\end{array}$ & 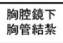 & 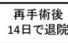 \\
\hline $\begin{array}{l}\text { 容下b } \\
2008\end{array}$ & $\begin{array}{l}61 \\
\text { 女1 }\end{array}$ & 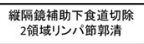 & $\begin{array}{c}1 \\
\text { твромо } \\
\end{array}$ & 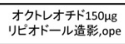 & 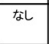 & $\begin{array}{c}\text { कDय } \\
\text { POD }\end{array}$ & 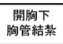 & 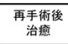 \\
\hline $\begin{array}{l}\text { 期谷的 } \\
2009\end{array}$ & $\begin{array}{l}74 \\
\text { 男 }\end{array}$ & 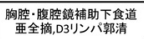 & $\begin{array}{ll}\text { 表在癌 } \\
\end{array}$ & な & - & 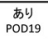 & 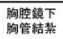 & 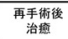 \\
\hline 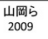 & $\begin{array}{l}62 \\
\text { 男 }\end{array}$ & 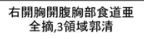 & $\begin{array}{c}\text { I } \\
\text { т16Nomo }\end{array}$ & 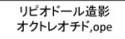 & ない & あり & 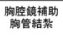 & 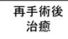 \\
\hline $\begin{array}{l}\text { 禁上b } \\
2009\end{array}$ & \begin{tabular}{|l|}
78 \\
男
\end{tabular} & 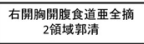 & $\underset{\text { PT30N2MO }}{\text { III }}$ & な & - & 部 & 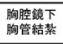 & 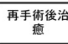 \\
\hline $\begin{array}{l}\text { WA⿵门 } \\
2009\end{array}$ & 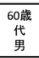 & 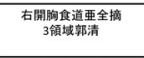 & 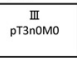 & 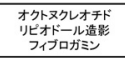 & \begin{tabular}{|l|l|} 
ない \\
\end{tabular} & 札 & - & $\begin{array}{ll}\text { PoO49 } \\
\text { F退期 }\end{array}$ \\
\hline $\begin{array}{l}\text { 䓦原的 } \\
2009\end{array}$ & $\begin{array}{l}58 \\
\text { 男 }\end{array}$ & 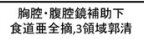 & $\begin{array}{c}\text { III } \\
\text { pT3PN2MO }\end{array}$ & オタトレオヂ300ug & ない & な & - & 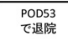 \\
\hline $\begin{array}{l}\text { 舟杖 } \\
2010\end{array}$ & $\begin{array}{l}63 \\
\text { 女 }\end{array}$ & 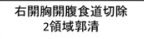 & $\begin{array}{c}\text { III } \\
\text { pT2pN1M0 }\end{array}$ & オタトレオヂ300ug & な & な & - & 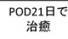 \\
\hline $\begin{array}{l}\text { 松谷战 } \\
2010\end{array}$ & \begin{tabular}{|l|}
67 \\
男
\end{tabular} & 胸粉镜下食道切除 & $\begin{array}{c}1 \\
\text { cT10Nomo } \\
\end{array}$ & $\begin{array}{c}\text { オタトレオヂ300ug } \\
\text { ope }\end{array}$ & な & 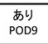 & 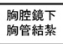 & $\begin{array}{l}\text { POD19飞 } \\
\text { ieg }\end{array}$ \\
\hline 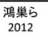 & \begin{tabular}{|l|l|}
68 \\
男
\end{tabular} & 右開洵開腹食道切除 & TisNomo & 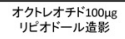 & ない & 札 & - & $\begin{array}{l}\text { POD62 } \\
\text { 退院 }\end{array}$ \\
\hline $\begin{array}{l}\text { 自驗何 } \\
2013 \\
\end{array}$ & $\begin{array}{l}65 \\
\text { 男 }\end{array}$ & 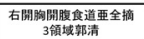 & $\begin{array}{c}\mathrm{II} \\
\mathrm{p} T 3 \text { गN1M0 }\end{array}$ & $\begin{array}{l}\text { Minomycine } \\
\text { オタトレオチト }\end{array}$ & ない & 札 & - & $\begin{array}{l}\text { PODS5T } \\
\text { 退院 }\end{array}$ \\
\hline
\end{tabular}


見からすると早期発症型であったため早期に手術適 応としても良かったのかもしれない. また癒着促進 のミノマイシンの投与時期としてはある程度の漸減 傾向が見られた時点で投入するべきであったと考え られ，本症例の投入時期は不適切であったといくつ かの反省点があげられる.

しかしながら本症例では脂肪制限食摄取，TPN 管理を併用することで栄養状態・循環動態は良好に 保たれ，長期化したものの安全に治癒することがで きた。

食道癌術後の乳糜胸ではその発生時期, 乳糜量, 全身状態を総合的に考慮して治療方針を決定すべき であるが，保存加療を継続するには徹底した栄養管 理を行うことも重要なポイントであると考えられ る.

おわりに

今回われわれは, 食道癌術後の乳糜胸の 1 例を経 験した，難治性で乳糜の漏出が持続したが，脂肪制 限食摂取およびTPN管理による徹底した栄養管理 を行い胸腔ドレナージ，酢酸オクトレオチド投与な ども行い治瘾を得たため若干の文献的考察を加えて 報告した.

\section{文献}

1) 森 昌造, 北村道彦. 術後管理. 新外科学大 系 - 食道外科, 中山書店。東京, $1988 ； 155$ 184.

2 ）渡辺明彦, 中谷勝紀, 宮城信行, 他. 食道癌切 除後に発生した乳糜胸の 1 治験例。臨外会誌 $1986 ； 41$ (4) : 509-512.

3 ）木村 亨, 船越康信, 竹内幸康, 他. 肺癌術後 乳糜胸についての臨床的検討。日呼外会誌 $2009 ; 23$ (2) : 120-125.

4) 植村 守, 土岐祐一郎, 石川 治, 他. リピオ ドールリンパ管造影にて治癒した食道癌術後難 治性乳糜胸水の 1 例。日消外会誌 $2005 ; 38$ (1) $: 7-12$.

5 ) 鴻巣正史, 木村祐輔, 岩谷 岳, 他. 食道癌術 後乳糜胸に対してリピオドールを用いたリンパ 管造影が奏効した 1 例。岩手医誌 $2012 ； 64$
(1) $: 63-69$.

6 ) 山田行重, 成清道博, 上野正闘, 他. オクトレ オチドが有効であった食道癌術後乳び胸の 1 例. 手術 2006；60（9）：1365-1369.

7 ) Ulibarri JI, Sanz Y, Fuentes C, et al. Reduction of limphorrhagia from ruptured thoracic duct by somatostatin. Lancet 1990 ; $336: 258$.

8 ) Kelly RF, Shumway SJ. Conservative management of postoperative chylothorax using somatostatin. Ann Thorac 2000; 69 : 1944-1945.

9 ) 立花慎吾, 逢坂由昭, 星野澄人, 他. 酢酸オク トレオチド投与, OK-432の胸腔内注入にて治 癒した食道癌術後遅発性乳糜胸の 1 例. 2006 ; 57 (1) : 35-39.

10）舟木 洋, 二宮 致, 伏田幸夫, 他. Octreotide acetate投与が有効であった食道・胃同時性重 複癌術後乳び胸の 1 例. $2010 ； 72$ (2) : 187190.

11）宮下正夫, 牧野浩司, 野村 務, 他. リピオド ールによるリンパ管造影が有効であった食道癌 術後乳び胸の 1 例。手術 2008；62（3）： 377-380.

12）藤原有史, 竹村雅至, 吉田佳世, 他. 保存的に 治瘺した食道癌術後乳び胸の 1 例。手術 $2009 ； 63$ (12) : 1859-1862.

13）松谷 毅, 内田英二, 丸山 弘, 他. 食道癌術 後乳び胸に対し胸腔鏡下胸管クリッピング術と octoreotide投与が有効であった 1 例. 外科 $2010 ; 72$ (7) : 763-765.

14）山村陽子, 沖津 宏, 田中麻美, 他. 食道癌術 後両側乳ビ胸に対し保存的加療で治癒した 1 例. Tokushima Red Cross Hospital Medical Journal $2009 ; 14: 75-79$.

15）山岡延樹, 宮川公治, 矢田善弘, 他. 食道癌術 後乳び胸の保存的治療後にリピオドールリンパ 管造影と胸胫鏡補助下手術が有効であった 1 例. 臨外 2009；64（1）：113-117.

16) Selle JG, Snyder WH, Schreiber JT. Chylothorax ; indication of surgery. Ann Surg $1992 ; 177: 245-249$.

17) Robinson CLH. The management of 
chylothorax (collective review). Ann Thorac Surg $1985 ; 39: 90-95$.

18) Patterson GA, Todd TRJ, Delarue NC, et al. Suparadiaphragmatic ligation of the thoracic duct in intractable chylous fistula. Ann Thorac Surg $1981 ; 32$ : 44-49.

19）大橋一郎，松原敏樹，木下 旗，他．食道癌切 除後に併発した乳び胸の治療。日消外会誌 $1990 ； 12: 296-302$.

20）村上慶洋, 山本和幸, 小出 亨, 他. 胸腔鏡が 有用であった食道術後乳び胸の 1 例. 外科 $2009 ； 71$ (4) : 430-433.

21）清水 哲, 渡辺淨司，中村誠一. 胸腔鏡下手術 が有効であった食道癌術後乳び胸の 1 例。日鏡 外会誌 $2008 ； 13$ (4) : 375-379.

22）細谷好則, 熊野秀俊, 瑞木 亨, 他. 食道癌切 除・後縱隔胃管再建術後の乳び胸に対して左側 アプローチの胸臆鏡下胸管クリッピングが有効 であった 1 例。手術 2009；63（10）：15651569.

23）鬼頭宗久, 小出直久, 斉藤拓康, 他. 呼吸不全 を伴った食道癌術後カイローマの 1 例。信州医 誌 $2006 ； 54$ （4）：197-201.

24）高木眞人, 岡田了祐, 青木利明, 他. オクトレ オチドが有効であった食道癌術後乳糜胸の 1

例. 日消外会誌 $2006 ； 39$ (2) : 164-169.

25）上吉原光宏, 懸川誠一, 川島 修, 他. 食道癌 手術後乳び胸に対する胸腔鏡下胸管クリッピン グの 1 例。胸部外科 $2005 ； 58 （ 13 ） ： 1189-$ 1191.

26）寺島秀夫，菅原宏文，平山 克. 胸部食道癌術 後の乳び胸に対する至適な手術手技－食道再建 経路を考慮した胸管への合理的な到達法．胸部 外科 $2003 ; 56$ (6) : 465-468.

27）木ノ下義宏, 宇田川晴司, 堤 謙二, 他. 食道 癌術後乳び胸に対する手術例。手術 $2002 ； 56$ (12) : 1981-1983.

\section{A Case of Post-Esophagectomy Chylothorax Treated by Consurvative Treatment with Octreotide.}

Hidefumi KUBO, Chiyo NAKASUGA, Kousuke TADA, Makoto MIYAHARA and Hiroyasu HASEGAWA

Department of Surgery, Tokuyama Central Hospital, 1-1 Koda-chou, Shuunan, Yamaguchi 745-8522, Japan

\section{SUMMARY}

We experienced a case in which conservative therapy including administration of octreotide acetate was effective for chylothorax after surgical treatment of esophageal cancer. A 65year-old male had received neoadjuvant chemotherapy and thereafter underwent subtotal esophagectomy with lymph node excision of three regions (c-T3N1M0, Stage III). On third postoperative day, pleural fluid of right pleural cavity was noted and an increase of drainarge fluid was observed and subsequently he was diagnosed as chylothorax. Octreotide acetate and mynomycine were administered daily but observed no dignificant improvement. The persistent conservative treatment, using fat-restricted diet and TPN, and a second infusion of octreotide acetate resulted in gradual decrease of discharge. On the $50^{\text {th }}$ postoperative day, the thoracic drainarge tube was removed and the $59^{\text {th }}$ postoperative day, the patient was discharged. We report this case presented with 24 literatures reported of chyrothorax after esophagectomy for esophageal cancer. 